\title{
EARLY POSTOPERATIVE OUTCOMES OF SURGICALLY TREATED AORTIC DISSECTION IN MARFAN SYNDROME PATIENTS
}

\author{
Ivan Nešić1, Jelena Dotlić2,3, Igor Živković1, Aleksandra Šljivić4 , Petar Vuković1,2, \\ Slobodan Mićović1,2, Petar Milačićc, ${ }^{1,2}$, Miroslav Miličić1,2, Djordje Zdravković ${ }^{1}$ \\ Milan Ćirković1 ${ }^{1}$ Miodrag Perić1,2
}

\begin{abstract}
Acute aortic dissection remains the leading cause of morbidity and mortality of Marfan syndrome patients. The study aimed to investigate the early postoperative outcomes of surgically treated aortic dissection in patients with Marfan syndrome. Study included all patients operated due to aortic dissection at the Cardiac Surgery Department, Dedinje Cardiovascular Institute in Belgrade during a six year period (2012-2017). Patients were divided regarding the diagnosis of Marfan syndrome. Preoperatively general data and detailed medical history were taken from every patient. Upon admission, patients underwent a thorough clinical and cardiologic examination. Patients were surgically treated according to current protocols. Postoperatively, patients were followed up for one month. During this follow-up period, we registered all complications and fatality. All pre and postoperatively collected data were compared and statistically analyzed. Study included 246 patients out of which $7.7 \%$ had Marfan syndrome. Marfan syndrome patients were significantly younger than control group patients $(p=0.001)$. There were no significant differences between patient groups regarding sex and smoking status. All patients with Marfan syndrome had dissection of type I. Marfan syndrome patients had fewer preoperative chronic illnesses and complications $(p=0.001)$. There were no significant differences in mortality $(p=0.702)$ and frequency of postoperative complications $(p=0.231)$ between patients with and without Marfan syndrome. In conclusion, it can be seen that prompt and adequate diagnosis and surgical treatment of aortic dissection can enable mostly good early postoperative outcomes in patients with Marfan syndrome.
\end{abstract}

Acta Medica Medianae 2020;59(1):36-43.

Key words: Marfan syndrome, aortic dissection, surgical treatment, outcome

\footnotetext{
${ }^{1}$ Cardiac Surgery Department, Dedinje Cardiovascular Institute, Belgrade, Serbia

${ }^{2}$ University of Belgrade, Medical Faculty, Belgrade, Serbia

${ }^{3}$ Clinic of Obstetrics and Gynecology, Clinical Center of Serbia, Belgrade, Serbia

${ }^{4}$ Department of Cardiology, University Clinical Hospital Center

"Dr Dragiša Mišović-Dedinje", Belgrade, Serbia
}

Contact: Ivan Nešić

Heroja Milana Tepića 1, 11000 Belgrade, Serbia

E-mail:dr.inesic@gmail.com

\section{Introduction}

Marfan syndrome is an autosomal dominant inherited disorder of the connective tissue in which cardiovascular, skeletal, ocular and other anomalies may be present to a variable degree (1). Its prevalence is around 1 in 5000 individuals. The combination of structural microfibril matrix abnormali- ties, deregulation of matrix homeostasis and inadequate cell-matrix interactions present the basis for clinical characteristics of the Marfan syndrome (2, 3).

The most common cardiovascular manifestations in patients with Marfan syndrome are progressive aortic dilatation and mitral valve prolapse. These anatomical abnormalities may cause mitral insufficiency as well as aortic insufficiency, aneurysm, dissection and even rupture (4). Surgical replacement of the dilated aortic root and ascending aorta has significantly increased the life expectancy of patients with Marfan syndrome. Nevertheless, acute aortic dissection remains the most important complication and the leading cause of morbidity and sudden death in these patients $(5,6)$.

Therefore, the study aim was to investigate the early postoperative outcomes of surgically treated aortic dissection in patients with Marfan syndrome.

\section{Materials and methods}

Study included all consecutive patients who were operated due to aortic dissection at the Cardiac 
Surgery Department, Dedinje Cardiovascular Institute in Belgrade during a six year period (January $1^{\text {st }}$ 2012 to December $31^{\text {st }}$ 2017). All patients were divided into study and control group based on the diagnosis of Marfan syndrome. Moreover, during preoperative assessment, fenotypical characteristics of Marfan syndrome followed in accordance with Ghent criteria were used for the preoperative diagnosis of Marfan syndrome.

For the study purpose, we took into consideration all parameters that could potentially impact the outcome of patients with aortic dissection, while the main tested outcomes were complications and fatality in early postoperative period.

Preoperatively, general data (age, sex and smoking status) as well as detailed medical history were taken from every patient. We registered if patients had chronic illnesses and/or symptoms/ complications associated with Marfan syndrome that could be the risk factors or signs of coronary illness such as hypertension, hyperlipoproteinemia, cerebrovascular insults, periphery vascular disease, chronic kidney insufficiency before operation and other minor symptoms/complications (fatigue, shortness of breath, heart palpitations, chest pain, cold extremities). Upon admission for operation, patients underwent a thorough clinical and cardiologic examination with echocardiography for visualization of the dissection localization and measuring the diameters of ascending, descending and abdominal aorta. Only dissections of the A type (Stanford classification) were included in the study. Dissections were further divided into type I and II according to DeBakey classification system. The heart ejection fraction and EuroSCORE (www.euroscore.org) were determined for each patient. Moreover, we registered if the patient had cerebrovasular insult or heart tamponade on admission to our institution as the gravest (major) preoperative complications.

Patients were all surgically treated according to current protocols for their condition (Bentall procedure; Interposition tube graft and resuspension of the aortic valve; Tirone David procedure; hemiarch replacement and arch replacement) $(7,8)$. We registered deep hypothermic cardiac arrest time, cross clamp time, cardiopulmonary bypass duration.

Postoperatively, patients were followed up for one month. During that period all complications were registered such as myocardial infarction, cerebrovascular insult, paralysis, kidney insufficiency, other minor complications (prolonged intensive care; need for intubation; revision of hemostasis; uncomplicated urinary infection; sternal wound infection) and/or lethal outcome.

All pre and postoperatively collected data were compared and statistically analyzed in the whole sample as well as in regards to the diagnosis of Marfan syndrome by applying methods of descriptive (mean, standard deviation, frequency and percent) and analytical statistics (ANOVA and Kuskal Wallis $\chi^{2}$ test). Spearman correlation was used to test the associations of investigated parameters and postoperative outcomes in the study group of patients with Marfan syndrome. We used SPSS 20 statistical software for Windows and $p$ value of 0.05 was set as the level of significance.

\section{Results}

Study included 246 patients out of which 19 $(7.7 \%)$ had Marfan syndrome while 227 were in the control group. Investigated patients were more often males $(p=0.001), 16$ to 86 years of age. At least one preoperative chronic illness and/or symptom/ complication (major or minor) were registered in $84.6 \%$ of our patients. Postoperative complications were also rather frequent (44.7\%), but in the overall sample, outcome was good for majority of patients $(80.9 \% ; p=0.001)$.

Preoperatively collected data as well as postoperative outcome of investigated patients in the study and control group are presented in Tables 1 and 2.

Table 1. Descriptive data of investigated patients in the study and control group

\begin{tabular}{|c|c|c|c|c|c|c|}
\hline \multirow[b]{2}{*}{ Parameters } & \multicolumn{2}{|c|}{ Marfan syndrome } & \multicolumn{2}{|c|}{ Control group } & \multirow[b]{2}{*}{$\mathrm{F}$} & \multirow[b]{2}{*}{$\mathrm{p}$} \\
\hline & Mean & $\begin{array}{l}\text { Standard } \\
\text { Deviation }\end{array}$ & Mean & $\begin{array}{l}\text { Standard } \\
\text { Deviation }\end{array}$ & & \\
\hline Patients age & 55.00 & 34.84 & 86.00 & (59.44 & 86.211 & 0.001 \\
\hline Ejection fraction & 65.00 & 55.27 & 65.00 & 54.46 & 0.164 & 0.686 \\
\hline Ascending aorta diameter $\mathrm{mm}$ & 90.00 & 56.66 & 83.00 & 53.38 & 1.902 & 0.169 \\
\hline Descending aorta diameter $\mathrm{mm}$ & 35.00 & 26.16 & 55.00 & 32.85 & 5.711 & 0.018 \\
\hline Abdominal aorta diameter $\mathrm{mm}$ & 22.00 & 22.01 & 61.00 & 25.26 & 0.070 & 0.793 \\
\hline EuroSCORE & 18.45 & 6.52 & 18.45 & 7.69 & 0.025 & 0.983 \\
\hline EuroSCORE 2 & 65.47 & 9.81 & 32.62 & 8.39 & 0.306 & 0.581 \\
\hline EuroSCORE + Log & 38.43 & 11.73 & 38.41 & 13.65 & 0.033 & 0.862 \\
\hline DHCA time min & 28.00 & 7.23 & 34.00 & 9.71 & 0.199 & 0.656 \\
\hline Cross clamp time min & 64.00 & 8.11 & 65.00 & 6.21 & 0.454 & 0.501 \\
\hline Cardiopulmonary bypass min & 141.00 & 49.68 & 132.00 & 61.31 & 0.398 & 0.529 \\
\hline
\end{tabular}

Legend: mm - millimeters; min - minutes; DHCA - deep hypothermic cardiac arrest time 
Table 2. Frequency of investigated parameters in study and control group

\begin{tabular}{|c|c|c|c|c|c|c|c|}
\hline \multirow{2}{*}{\multicolumn{2}{|c|}{ Parameters }} & \multicolumn{2}{|c|}{ Marfan syndrome } & \multicolumn{2}{|c|}{ Control group } & \multirow{2}{*}{$\mathrm{KW} \chi^{2}$} & \multirow{2}{*}{$\mathrm{p}$} \\
\hline & & Number & $\%$ & Number & $\%$ & & \\
\hline \multirow{2}{*}{ Patients sex } & male & 14 & 73.7 & 168 & 74.0 & \multirow{2}{*}{0.001} & \multirow{2}{*}{0.975} \\
\hline & female & 5 & 26.3 & 59 & 26.0 & & \\
\hline \multirow{2}{*}{ Smoking } & no & 8 & 42.1 & 119 & 52.4 & \multirow{2}{*}{0.744} & \multirow{2}{*}{0.388} \\
\hline & yes & 11 & 57.9 & 108 & 47.6 & & \\
\hline \multirow{2}{*}{ Dissection type } & one & 19 & 100 & 194 & 85.5 & \multirow{2}{*}{7.177} & \multirow{2}{*}{0.035} \\
\hline & two & 0 & 0 & 33 & 14.5 & & \\
\hline \multirow{2}{*}{ Hypertension } & no & 16 & 84.2 & 59 & 26.0 & \multirow{2}{*}{27.927} & \multirow{2}{*}{0.001} \\
\hline & yes & 3 & 15.8 & 168 & 74.0 & & \\
\hline \multirow{2}{*}{$\begin{array}{l}\text { Hyperlipo - } \\
\text { protainaemia }\end{array}$} & no & 19 & 100 & 186 & 81.9 & \multirow{2}{*}{4.101} & \multirow{2}{*}{0.043} \\
\hline & yes & 0 & 0 & 41 & 18.1 & & \\
\hline \multirow{2}{*}{ CVI before } & no & 18 & 94.7 & 211 & 93.0 & \multirow{2}{*}{0.087} & \multirow{2}{*}{0.769} \\
\hline & yes & 1 & 5.3 & 16 & 7.0 & & \\
\hline \multirow{2}{*}{$\begin{array}{l}\text { Periphery vascular } \\
\text { disease }\end{array}$} & no & 18 & 94.7 & 207 & 91.2 & 1.815 & 0.178 \\
\hline & yes & 1 & 5.3 & 20 & 8.8 & 1.810 & $0.1 / 8$ \\
\hline Chronic kidney & no & 19 & 100 & 218 & 96.0 & 3779 & 0.049 \\
\hline insufficiency & yes & 0 & 0 & 9 & 4.0 & 3.178 & 0.049 \\
\hline Coronary illness & no & 19 & 100 & 194 & 85.5 & 7177 & 0035 \\
\hline before operation & yes & 0 & 0 & 33 & 14.5 & 8.18 & 0.03 \\
\hline Tamponade on & no & 16 & 84.2 & 167 & 73.6 & 1038 & 0308 \\
\hline admission & yes & 3 & 15.8 & 60 & 26.4 & 1.030 & 0.300 \\
\hline Cerebrovascular & no & 18 & 94.7 & 207 & 91.2 & 0.227 & 0.529 \\
\hline insult on admission & yes & 1 & 5.3 & 20 & 8.8 & $0.2<1$ & \\
\hline Other symptoms and & no & 17 & 89.5 & 196 & 86.3 & 0.147 & 0.701 \\
\hline complications & yes & 2 & 10.5 & 31 & 13.7 & $0.14 \%$ & 0.101 \\
\hline Had some preop. & no & 10 & 52.6 & 28 & 12.3 & 21.709 & 0.001 \\
\hline complications & yes & 9 & 47.4 & 199 & 87.7 & & \\
\hline Myocardial infarct & no & 19 & 100 & 222 & 97.8 & 3425 & 0.049 \\
\hline postoperatively & yes & 0 & 0 & 5 & 2.2 & 3.425 & 0.049 \\
\hline Cerebrovascular & no & 18 & 94.7 & 196 & 86.3 & 1087 & (297 \\
\hline insult postop. & yes & 1 & 5.3 & 31 & 13.7 & 1.001 & 0.251 \\
\hline Postoperative & no & 18 & 94.7 & 225 & 99.1 & 2783 & 0095 \\
\hline paralysis & yes & 1 & 5.3 & 2 & 0.9 & 2.103 & 0.093 \\
\hline Postop. kidney & no & 17 & 89.5 & 200 & 88.1 & 0,031 & 0859 \\
\hline insufficiency & yes & 2 & 10.5 & 27 & 11.9 & 0.031 & 0.859 \\
\hline Other postop. & no & 8 & 42.1 & 154 & 67.8 & 5.143 & 0.023 \\
\hline complications & yes & 11 & 57.9 & 73 & 32.2 & 3.143 & 0.023 \\
\hline Had some postop. & no & 8 & 42.1 & 128 & 56.4 & 1441 & 0.231 \\
\hline complications & yes & 11 & 57.9 & 99 & 43.6 & & \\
\hline Postoperative lethal & no & 16 & 84.2 & 183 & 80.6 & 0.146 & 27.70 \\
\hline outcome & yes & 3 & 15.8 & 44 & 19.4 & 0.140 & \\
\hline
\end{tabular}

Legend: preop - preoperative; postop - postoperative

In our sample patients with Marfan syndrome were significantly younger than patients from the control group. There were no significant differences between patient groups regarding sex and smoking status. All patients with Marfan syndrome had dissection of type I.

Investigated patients with Marfan syndrome in general were healthier preoperatively than patients from the control group. Compared to patients from the control group significantly fewer patients with Marfan syndrome had hyperlipoproteinemia and hypertension, while there were no patients with
Marfan syndrome who had chronic kidney insufficiency and coronary illness. Periphery vascular disease and cerebrovascular insults were found with similar frequency in both patient groups.

On examination upon admission for operation, patients from both groups had comparable ejection fraction as well as diameters of ascending and abdominal aorta preoperatively. On the other hand, descending aorta had larger diameter in patients of the control group than with Marfan syndrome. Still, EuroSCORE for both patient groups with and without Marfan syndrome was 18.45 . 
Table 3. Correlations of investigated parameters and postoperative outcomes

\begin{tabular}{|c|c|c|c|}
\hline \multicolumn{2}{|l|}{ Parameters } & $\begin{array}{c}\text { Early postoperative } \\
\text { lethal outcome }\end{array}$ & $\begin{array}{c}\text { Early postoperative } \\
\text { complications }\end{array}$ \\
\hline \multirow{2}{*}{$\begin{array}{l}\text { All early postoperative } \\
\text { complications }\end{array}$} & rho & 0.963 & / \\
\hline & $\mathrm{p}$ & 0.012 & / \\
\hline \multirow{2}{*}{ Patients age } & rho & -0.171 & 0.156 \\
\hline & $\mathrm{p}$ & 0.483 & 0.524 \\
\hline \multirow{2}{*}{ Patients sex } & rho & -0.259 & -0.217 \\
\hline & $p$ & 0.285 & 0.373 \\
\hline \multirow{2}{*}{ Hypertension } & rho & -0.188 & 0.369 \\
\hline & $\mathrm{p}$ & 0.442 & 0.120 \\
\hline \multirow{2}{*}{ Smoking status } & rho & 0.508 & -0.295 \\
\hline & $\mathrm{p}$ & 0.026 & 0.219 \\
\hline \multirow{2}{*}{ Cerebrovascular insult before } & rho & -0.102 & -0.276 \\
\hline & $\mathrm{p}$ & 0.678 & 0.252 \\
\hline \multirow{2}{*}{ Ejection fraction } & rho & 0.106 & 0.045 \\
\hline & $\mathrm{p}$ & 0.676 & 0.858 \\
\hline \multirow{2}{*}{$\begin{array}{l}\text { Ascending aorta diameter } \\
\text { (millimeters) }\end{array}$} & rho & 0.446 & -0.630 \\
\hline & $\mathrm{p}$ & 0.063 & 0.094 \\
\hline \multirow{2}{*}{$\begin{array}{l}\text { Descending aorta diameter } \\
\text { (millimeters) }\end{array}$} & rho & -0.630 & -0.169 \\
\hline & $\mathrm{p}$ & 0.094 & 0.689 \\
\hline \multirow{2}{*}{$\begin{array}{l}\text { Abdominal aorta diameter } \\
\text { (millimeters) }\end{array}$} & rho & 0.369 & 0.369 \\
\hline & $\mathrm{p}$ & 0.120 & 0.120 \\
\hline \multirow{2}{*}{ Tamponade on admission } & rho & 0.208 & 0.077 \\
\hline & $\mathrm{p}$ & 0.392 & 0.754 \\
\hline \multirow{2}{*}{$\begin{array}{l}\text { Cerebrovascular insult on } \\
\text { admission }\end{array}$} & rho & -0.102 & 0.201 \\
\hline & $\mathrm{p}$ & 0.678 & 0.409 \\
\hline \multirow{2}{*}{$\begin{array}{l}\text { Other symptoms and } \\
\text { complications preoperatively }\end{array}$} & rho & -0.149 & 0.293 \\
\hline & $\mathrm{p}$ & 0.544 & 0.224 \\
\hline \multirow{2}{*}{$\begin{array}{l}\text { Had some preoperative } \\
\text { complications / symptoms }\end{array}$} & rho & -0.122 & 0.382 \\
\hline & $\mathrm{p}$ & 0.620 & 0.106 \\
\hline \multirow{2}{*}{ EuroSCORE } & rho & -0.630 & 0.369 \\
\hline & $\mathrm{p}$ & 0.094 & 0.120 \\
\hline \multirow{2}{*}{ EuroSCORE 2} & rho & 0.045 & 0.318 \\
\hline & $\mathrm{p}$ & 0.858 & 0.313 \\
\hline \multirow{2}{*}{ EuroSCORE Log } & rho & 0.369 & 0.201 \\
\hline & $\mathrm{p}$ & 0.120 & 0.409 \\
\hline \multirow{2}{*}{$\begin{array}{l}\text { Deep hypothermic cardiac } \\
\text { arrest time (minutes) }\end{array}$} & rho & 0.522 & 0.159 \\
\hline & $\mathrm{p}$ & 0.032 & 0.543 \\
\hline \multirow{2}{*}{ Cross clamp time (minutes) } & rho & 0.072 & 0.216 \\
\hline & $p$ & 0.777 & 0.390 \\
\hline \multirow{2}{*}{$\begin{array}{l}\text { Cardiopulmonary bypass } \\
\text { duration (minutes) }\end{array}$} & rho & 0.145 & 0.477 \\
\hline & $p$ & 0.554 & 0.039 \\
\hline
\end{tabular}

Legend: Bold - significant

There were no significant differences in duration of hypothermic cardiac arrest as well as the time on the cross clamp between groups.
In the early postoperative period patients from the control group more often developed myocardial infarction, while patients with Marfan 
syndrome postoperatively more often had other minor complications. Still, when all postoperative complications were assessed together there were no significant differences in their frequency between groups.

Lethal outcome after the operation for aortic dissection was generally not very frequent in our sample and occurred in similar percent of patients with and without Marfan syndrome.

Finally, in the study group of patients with Marfan syndrome postoperative lethal outcome significantly correlated with having early postoperative complications, being a smoker and longer duration of hypothermic cardiac arrest, while early postoperative complications were associated with longer duration of cardiopulmonary bypass (Table 3 ).

\section{Discussion}

Marfan syndrome is caused by more than a thousand currently described mutations in the fibrillin-1 (FBN1) gene (on chromosome 15) encoding a glycoprotein which is a principal component of the extracellular matrix microfibril $(2,3)$. Therefore, major clinical features of this syndrome result from weaker connective tissues caused by defects in fibrillin-1, but the extent of signs and symptoms are highly variable because of varying genotype expression (1). Moreover, some studies have shown that in Marfan syndrome, function of transforming growth factor beta (TGF- $\beta$ ), stimulator of inflammation, fibrosis and activator of matrix metalloproteinase 2 and 9, is abnormal (9). Increased TGF- $\beta$ activation in tissues can cause failure of lung septation, development of a myxomatous mitral valve and aortic root dilation. In addition, as the destruction of the elastic and collagen lamellae progresses over time, the loss of elasticity in the media causes increased aortic stiffness and decreased distensibility. Therefore, due to the loss of appropriate medial layer support, aortic dissections are facilitated $(2,3,9)$. Therefore, it is considered that nearly all patients with Marfan syndrome will develop cardiovascular disease over their lifetimes, most frequently aortic root enlargement with associated aortic regurgitation, thoracic aortic aneurysm, aortic dissection or mitral valve prolapse (10).

Although nowadays there are well established clinical criteria and available genetic tests, Marfan syndrome patients are still diagnosed late. Consequently numerous patients do not get specialist care before they develop complications $(6,7)$. According to the data of a large study covering 20 years period conducted by The International Registry on Acute Aortic Dissections around 4\% of patients with acute aortic dissection had Marfan syndrome (1). Studies on Marfan syndrome patient cohorts reported that around $36 \%$ of patients have an aortic event. The incidence of aortic complications at the age of 20 is less than $5 \%$ and it increase up to $50 \%$ by the age of 50 years $(5,10,11)$. In our sample Marfan syndrome was somewhat more frequent reaching $7.7 \%$.

Different studies indicate that patients with Marfan syndrome have aortic dissection more often at a significantly younger age compared to patients without Marfan syndrome. On the other hand, because of their younger age, they were found to generally have less other comorbidities $(12,13)$. Patients with Marfan syndrome mostly have lower incidence of hypertension, atherosclerosis and diabetes mellitus, acute renal failure and stroke, while they more frequently have aortic aneurysms, aortic insufficiency grade 3 or 4 and prior cardiac surgery $(1,6)$. The same was confirmed in our study as well. Males were found to have a significantly increased risk of aortic events compared with women. In addition, aortic complications happened earlier in males than in females $(8,11)$. Our study also showed that male Marfan patients were significantly more often affected by acute dissection than women $(73.7 \%$ vs. $26.3 \%)$. It is not clear why aortic dissection in Marfan syndrome occurs more frequently in men, but there are several hypotheses, including a still unknown protective effect of the $X$ chromosome in women. This is suggested by the fact that women with a deficiency of the $X$ chromosome (Turner syndrome) have a significantly increased risk of aortic disease, including dissection $(2,14)$.

Available data show that distribution of type A and B dissection seems to occur with a similar frequency in both patients with and without Marfan syndrome (11). In our sample, type II dissection was only registered in the control group patients. Moreover, the diameter of descending aorta was significantly larger in the control group patients than in patients with Marfan syndrome. In some investigations, significantly larger diameters of the aortic annulus and root were registered in Marfan syndrome patients with aortic dissections, but not larger diameters more distally $(1,15)$. In our sample, patients with and without Marfan syndrome had similar diameters of ascending and abdominal aorta. However, neither of the preoperatively measured diameters of the aorta was associated with early postoperative complications or outcomes in Marfan syndrome patients.

Another interesting observation from the literature is that the incidence of aortic rupture appears to be lower in Marfan syndrome, as suggested by the lower incidence of pericardial effusion and periaortic hematoma on preoperative imaging $(1,10)$. Contrary, in our study no significant differences in preoperative tamponade occurrence were noted between patients with and without Marfan syndrome.

Open aortic repair is the gold standard for treating patients with aortic dissection. The aortic root is commonly replaced while some patients may also need distal aortic repair $(7,8,15,16)$. Despite improvement in prevention and surgical techniques, aortic aneurysm repair is still a high-risk operation for patients with Marfan syndrome (17). Failure to extend the primary surgery to aortic root or arch repair was found to correlate with more postoperative complications $(13,18)$. However, elective repair of aortic aneurysms in Marfan syndrome patients usually has excellent survival and postoperative quality of life. Mortality in urgent or emergent repair is somewhat higher, but still quite acceptable (18-20). 
The mortality rates in the first month after surgery for aortic dissection vary in literature data. Some centers managed to achieve very low early postoperative adverse events ( 2 to $6 \%$ of Marfan syndrome patients) which mostly occurred due to intraoperative ruptures $(10,11)$. In the USA authors reported $4.4 \%$ 30-day mortality in patients with Marfan syndrome who underwent urgent ascending aortic repair. Postoperative survival is usually above $60 \%$ even in case of reintervention (18). Other findings showed that the overall in-hospital mortality rate after surgery is $10.9 \%$ in patients with Marfan syndrome compared to $16.9 \%$ in patients without Marfan syndrome $(1,19)$. The early mortality in type A dissection was not significantly different in patients with or without Marfan syndrome, but in case of type B dissection mortality was lower in patients without Marfan syndrome $(4,13)$. In our sample, inhospital mortality was not high and comparable with the mortality currently reported for the overall aortic dissection population, which ranges between $8 \%$ and $20 \%$ in high-volume centers $(1,20)$. In our study there were no significant differences in early postoperative mortality of patients with and without Marfan syndrome.

According to the literature data, risk factors for adverse postoperative outcome in Marfan syndrome patients were younger age at surgery, postoperative use of ECMO, post-operative hemorrhage, neurologic complication and having additional coronary artery procedure $(10,16,17)$. Sex and race/ ethnicity were not associated with mortality after surgery for aortic dissection regardless of having or not the Marfan syndrome $(5,10)$. We found that in Marfan syndrome patients, postoperative lethal outcome was associated with having early postoperative complications, being a smoker and longer duration of hypothermic cardiac arrest, while early postoperative complications were associated with longer duration of cardiopulmonary bypass.

Postoperative complications after surgery for aortic dissection are mostly common in available studies reaching $45 \%(5,20)$. The most frequently reported complications were arrhythmia, post-ope- rative hemorrhage, pericardial complications and respiratory complications (10). The most common complications in Marfan syndrome patients are pulmonary complications. Postoperative neurological complications occurred only in patients with Marfan syndrome (1). On the other hand, permanent stroke and paraplegia, gastrointestinal ischemia as well as renal failure were found to occur rarely in Marfan syndrome patients $(16,19)$. In our study postoperative complications were registered in around $50 \%$ of patients, but there were no significant differences in their frequency between patients with and without Marfan syndrome. Moreover, Marfan syndrome patients postoperatively more often had only minor complications. These good results are probably related to the relatively young age at the time of surgery and low prevalence of comorbidities in patients with Marfan syndrome.

\section{Conclusion}

Results of our study show that with prompt and adequate diagnosis and surgical treatment of aortic dissection early postoperative outcomes in patients with Marfan syndrome are mostly good. Mortality rates of Marfan syndrome patients are low and postoperative complications are minor. Moreover, the outcomes of surgically treated aortic dissections are generally comparable in patients with and without Marfan syndrome. The parameters that impact Marfan syndrome patients' postoperative outcome are longer duration of cardiopulmonary bypass and hypothermic cardiac arrest, having early postoperative complications and being a smoker.

\section{Conflict of interest}

Authors declare that they have no conflict of interest.

Funding: This research did not receive any funding. 


\section{References}

1. De Beaufort HW, De Beaufort HW, Trimarchi S, Korach A, Di Eusanio M, Gilon D, Montgomery DG, et al. Aortic dissection in patients with Marfan syndrome based on the IRAD data. Ann Cardiothorac Surg 2017; 6:633-41. [CrossRef] [PubMed]

2. Pyeritz RE. Etiology and pathogenesis of the Marfan syndrome: current understanding. Ann Cardiothorac Surg 2017;6:595-8. [CrossRef] [PubMed]

3. De Backer J. Cardiovascular characteristics in Marfan syndrome and their relation to the genotype. Verh $\mathrm{K}$ Acad Geneeskd Belg 2009;71:335-71. [PubMed]

4. Schoenhoff FS, Jungi S, Czerny M, Roost E, Reineke D, Matyas G, et al. Acute aortic dissection determines the fate of initially untreated aortic segments in Marfan syndrome. Circulation 2013;127:1569-75. [CrossRef] [PubMed]

5. Wagner $A H$, Zaradzki $M$, Arif $R$, Remes A, Muller OJ, Kallenbach K. Marfan syndrome: A therapeutic challenge for long-term care. Biochem Pharmacol 2019; 164:53-63. [CrossRef] [PubMed]

6. Groth KA, Stochholm $\mathrm{K}$, Hove $\mathrm{H}$, Andersen $\mathrm{NH}$, Gravholt $\mathrm{CH}$. Causes of Mortality in the Marfan Syndrome (from a Nationwide Register Study). Am J Cardiol 2018;122:1231-5. [CrossRef] [PubMed]

7. Milewicz DM, Ramirez F. Therapies for Thoracic Aortic Aneurysms and Acute Aortic Dissections. Arterioscler Thromb Vasc Biol 2019;39:126-36. [CrossRef] [PubMed]

8. Zehr KJ, Matloobi A, Connolly HM, Orszulak TA, Puga FJ, Schaff HV. Surgical management of the aortic root in patients with Marfan syndrome. J Heart Valve Dis 2005;14:121-8. [PubMed]

9. Overwater $E$, Efrat $R$, Barge-Schaapveld DQCM, Lakeman $P$, Weiss MM, Maugeri $A$, et al. Autosomal dominant Marfan syndrome caused by a previously reported recessive FBN1 variant. Mol Genet Genomic Med 2019;7(2):e00518. [CrossRef] [PubMed]

10. Knadler JJ, LeMaire S, McKenzie ED, Moffett B, Morris SA. Thoracic Aortic, Aortic Valve and Mitral Valve Surgery in Pediatric and Young Adult Patients with Marfan Syndrome: Characteristics and Outcomes. Semin Thorac Cardiovasc Surg 2019;31(4):818-25. [CrossRef] [PubMed]

11. Groth KA, Stochholm K, Hove H, Kyhl K, Gregersen PA, Vejlstrup $N$, et al. Aortic events in a nationwide
Marfan syndrome cohort. Clin Res Cardiol 2017;106: 105-12. [CrossRef] [PubMed]

12. Zhu S, Zheng T, Qiao ZY, Chen L, Ou JF, Fang WG, et al. Acute Aortic Dissection in Young Adult Patients: Clinical Characteristics, Management, and Perioperative Outcomes. J Invest Surg 2019; [CrossRef] [PubMed]

13. Vanem TT, Geiran OR, Krohg-Sorensen K, Roe C, Paus $B$, Rand-Hendriksen S. Survival, causes of death, and cardiovascular events in patients with Marfan syndrome. Mol Genet Genomic Med 2018;6:1114-23. [CrossRef] [PubMed]

14. Weinsaft JW, Devereux RB, Preiss LR, Feher A, Roman $\mathrm{MJ}$, Basson CT, et al. Aortic Dissection in Patients With Genetically Mediated Aneurysms: Incidence and Predictors in the GenTAC Registry. J Am Coll Cardiol 2016;67:2744-54. [CrossRef] [PubMed]

15. Keane MG, Pyeritz RE. Medical management of Marfan syndrome. Circulation 2008;117:2802-13. [CrossRef] [PubMed]

16. Coselli JS, Green SY, Price MD, Hash JA, Ouyang Y, Volguina IV, et al. Results of Open Surgical Repair in Patients With Marfan Syndrome and Distal Aortic Dissection. Ann Thorac Surg 2016;101:2193-201. [CrossRef] [PubMed]

17. Holscher CM, Dakour Aridi $\mathrm{H}$, Locham SS, Hicks CW, Canner JK, Malas M, et al. Aortic Surgery Outcomes of Marfan Syndrome and Ehlers-Danlos Syndrome Patients at Teaching and Nonteaching Hospitals. Ann Vasc Surg 2019;55:175-81.e3. [CrossRef] [PubMed]

18. Rylski B, Bavaria JE, Beyersdorf F, Branchetti $E$, Desai ND, Milewski RK, et al. Type A aortic dissection in Marfan syndrome: extent of initial surgery determines long-term outcome. Circulation 2014;129:1381-6. [CrossRef] [PubMed]

19. Attenhofer Jost $\mathrm{CH}$, Connolly HM, Scott CG, Ammash NM, Bowen JM, Schaff HV. Aortic Root Surgery in Marfan Syndrome: Medium-Term Outcome in a Single-Center Experience. J Heart Valve Dis 2017; 26: 45-53. [PubMed]

20. Yetman AT, Bornemeier RA, McCrindle BW. Long-term outcome in patients with Marfan syndrome: is aortic dissection the only cause of sudden death? J Am Coll Cardiol 2003;41:329-32. [CrossRef] [PubMed] 


\title{
RANI POSTOPERATIVNI ISHODI HIRURŠKI TRETIRANE AORTNE DISEKCIJE KOD BOLESNIKA SA MARFANOVIM SINDROMOM
}

\author{
Ivan Nešić1, Jelena Dotlić2,3, Igor Živković1, Aleksandra Šljivić4 , Petar Vuković1,2, \\ Slobodan Mićović1, ${ }^{2}$, Petar Milačić1, ${ }^{2}$, Miroslav Miličić1,2, Đorđe Zdravković1, \\ Milan Ćirković1, Miodrag Perić1,2
}

\author{
${ }^{1}$ Klinika za kardiohirurgiju, Institut za kardiovaskularne bolesti "Dedinje", Beograd, Srbija \\ 2Univerzitet u Beogradu, Medicinski fakultet, Beograd, Srbija \\ ${ }^{3}$ Klinika za ginekologiju i akušerstvo Kliničkog centra Srbije, Beograd, Srbija \\ ${ }^{4}$ Odeljenje za kardiologiju, Kliničko-bolnički centar "Dr Dragiša Mišović - Dedinje", Beograd, Srbija
}

Kontakt: Ivan Nešić

Heroja Milana Tepića 1, 11000 Beograd, Srbija

E-mail: dr.inesic@gmail.com

\begin{abstract}
Akutna disekcija aorte ostaje vodeći uzrok morbiditeta i mortaliteta bolesnika sa Marfanovim sindromom. Studija je imala za cilj da ispita rane postoperativne ishode hirurški tretirane disekcije aorte kod bolesnika sa Marfanovim sindromom. Studija je obuhvatila sve bolesnike operisane zbog disekcije aorte na Klinici za kardiohirurgiju Instituta za kardiovaskularne bolesti "Dedinje" u Beogradu, tokom perioda od šest godina (2012. - 2017.). Bolesnici su bili podeljeni u odnosu na postojanje dijagnoze Marfanovog sindroma. Preoperativno od svakog bolesnika uzeti su opšti podaci i detaljna medicinska istorija. Nakon prijema, bolesnici su bili podvrgnuti temeljnom kliničkom i kardiološkom pregledu. Bolesnici su hirurški tretirani prema aktuelnim protokolima. Postoperativno, bolesnici su praćeni mesec dana. Tokom ovog perioda praćenja registrovane su sve komplikacije i registrovana je smrtnost. Svi preoperativno i postoperativno prikupljeni podaci upoređeni su i statistički analizirani. Studija je obuhvatila 246 bolesnika od kojih je 7,7\% imalo Marfanov sindrom. Bolesnici sa Marfanovim sindromom bili su značajno mlađi od bolesnika kontrolne grupe ( $p=$ 0,001 ). Nije bilo značajnih razlika između grupa bolesnika u pogledu pola i pušačkog statusa. Svi bolesnici sa Marfanovim sindromom imali su disekciju tipa I. Bolesnici sa Marfanovim sindromom imali su manje preoperativnih hroničnih bolesti i komplikacija $(p=0,001)$. Nije bilo značajnih razlika u mortalitetu $(p=0,702)$ i učestalosti postoperativnih komplikacija $(p=$ 0,231 ) između bole-snika sa Marfanovim sindromom i bez Marfanovog sindroma. U zaključku se može videti da brza i adekvatna dijagnoza i hirurško lečenje disekcije aorte mogu omogućiti uglavnom dobre rane postoperativne ishode kod bolesnika sa Marfanovim sindromom.
\end{abstract}

Acta Medica Medianae 2020;59(1):36-43.

Ključne reči: Marfanov sindrom, disekcija aorte, hirurški tretman, ishod 